\title{
Effect of carbon-to-nitrogen ratio on high- rate nitrate removal in an upflow sludge blanket reactor for polluted raw water pre- treatment application
}

\author{
Seow Wah How ${ }^{1}$, Choo Xiang Ting ${ }^{1}$, Jing Ying Yap ${ }^{1}$, Ching Yi Kwang ${ }^{1}$, Chee Keong Tan', \\ Wilasinee Yoochatchaval ${ }^{2}$, Kazuaki Syutsubo ${ }^{3}$ and Adeline Seak May Chua ${ }^{1 *}$ (D)
}

\begin{abstract}
The drinking water treatment plants (DWTPs) in the developing countries urgently need an efficient pre-treatment for nitrate $\left(\mathrm{NO}_{3}{ }^{-}\right.$) removal to cope with the increasing $\mathrm{NO}_{3}{ }^{-}$pollution in raw water. An upflow sludge blanket (USB) reactor applied for $\mathrm{NO}_{3}{ }^{-}$removal from domestic wastewater may be adopted by the DWTPs. However, studies on the optimal carbon-to-nitrogen ratio (C/N) and operation of USB reactor at short hydraulic retention times (HRT) for high-rate polluted raw water pre-treatment are lacking. In this study, we first investigated the optimal $\mathrm{C} / \mathrm{N}$ for biological $\mathrm{NO}_{3}{ }^{-}$removal in a sequencing batch reactor (SBR). An USB reactor was then operated with the optimal $\mathrm{C} / \mathrm{N}$ for pre-treating synthetic raw water contaminated with $\mathrm{NO}_{3}{ }^{-}\left(40 \mathrm{mg} \mathrm{N} \mathrm{L}^{-1}\right)$ to monitor the $\mathrm{NO}_{3}{ }^{-}$removal performance and to examine opportunities for reducing the HRT. After operating the SBR with designed C/N of 4, 3 and $2 \mathrm{~g} \mathrm{C} \mathrm{g}^{-1} \mathrm{~N}$, we selected $\mathrm{C} / \mathrm{N}$ of $3 \mathrm{~g} \mathrm{C} \mathrm{g}^{-1} \mathrm{~N}$ as the optimal ratio due to the lower carbon breakthrough and nitrite $\left(\mathrm{NO}_{2}^{-}\right)$accumulation in the SBR. The USB reactor achieved complete $\mathrm{NO}_{3}{ }^{-}$and $\mathrm{NO}_{2}{ }^{-}$removal with a lower designed $\mathrm{C} / \mathrm{N}$ of $2 \mathrm{~g} \mathrm{C} \mathrm{g}^{-1} \mathrm{~N}$ due to the longer sludge retention time when compared with that of SBR (10 d). The high specific denitrification rate $\left(18.7 \pm 3.6 \mathrm{mg} \mathrm{N} \mathrm{g}^{-1}\right.$ mixed liquor volatile suspended solids $\left.\mathrm{h}^{-1}\right)$ suggested a possible HRT reduction to $36 \mathrm{~min}$. We successfully demonstrated an USB reactor for high-rate $\mathrm{NO}_{3}{ }^{-}$removal, which could be a promising technology for DWTPs to pre-treat raw water sources polluted with $\mathrm{NO}_{3}{ }^{-}$.
\end{abstract}

Keywords: Denitrification, Hydraulic retention time, Nitrate contamination, Sequencing batch reactor, Sludge retention time

\section{Introduction}

Nitrate $\left(\mathrm{NO}_{3}{ }^{-}\right)$pollution is increasingly threatening the water quality in many developing countries undergoing rapid urbanization, mainly due to agricultural runoffs, livestock wastewater and discharge of inadequately treated domestic wastewater. For example, Malaysia is one these developing countries experiencing temporal elevated nitrate nitrogen $\left(\mathrm{NO}_{3}{ }^{-}-\mathrm{N}\right)$ up to $35 \mathrm{mg} \mathrm{L}^{-1}$ in rivers $[1,2]$. To prevent

\footnotetext{
* Correspondence: adeline@um.edu.my

'Department of Chemical Engineering, Faculty of Engineering, Universiti

Malaya, 50603 Kuala Lumpur, Malaysia

Full list of author information is available at the end of the article
}

elevated $\mathrm{NO}_{3}{ }^{-}$pollution from causing public health concerns, World Health Organization [3] recommended that $\mathrm{NO}_{3}{ }^{-} \mathrm{N}$ in drinking water must not exceed $10 \mathrm{mg} \mathrm{L}^{-1}$.

Most of the drinking water treatment plants (DWTPs) in the developing countries lack a treatment technology for $\mathrm{NO}_{3}{ }^{-}$removal from raw water because most of these plants are still using conventional process [4]. Thus, research study on a robust raw water pre-treatment technology for $\mathrm{NO}_{3}{ }^{-}$removal is urgently needed to protect the public health.

In recent years, biological denitrification treatment is gaining attention in $\mathrm{NO}_{3}^{-}$removal rather than ion

(c) The Author(s). 2021 Open Access This article is licensed under a Creative Commons Attribution 4.0 International License, which permits use, sharing, adaptation, distribution and reproduction in any medium or format, as long as you give

appropriate credit to the original author(s) and the source, provide a link to the Creative Commons licence, and indicate if changes were made. The images or other third party material in this article are included in the article's Creative Commons licence, unless indicated otherwise in a credit line to the material. If material is not included in the article's Creative Commons licence and your intended use is not permitted by statutory regulation or exceeds the permitted use, you will need to obtain permission directly from the copyright holder. To view a copy of this licence, visit http://creativecommons.org/licenses/by/4.0/. 
exchange, catalytic reduction, or reverse osmosis due to its high efficiency, low cost, and capability of converting $\mathrm{NO}_{3}{ }^{-}$into inert nitrogen gas $[5,6]$. Biological denitrification was commonly reported for $\mathrm{NO}_{3}{ }^{-}$removal from domestic wastewater in activated sludge process [7-9]. Besides using activated sludge, using an upflow sludge blanket (USB) reactor for biological denitrification could encourage the agglomeration of sludge into granules. The sludge granulation occurred through the washout of light flocs, while sludge with good settleability remained in the USB reactor could agglomerate into granules [10, 11]. The granular sludge in the USB reactor may retain very high biomass concentration $\left(7-130 \mathrm{~g} \mathrm{~L}^{-1}\right)$ to promote high-rate $\mathrm{NO}_{3}{ }^{-}$removal from the domestic wastewater [11-13]. For example, Watari et al. [11] reported granular sludge $3.8 \mathrm{~mm}$ in diameter with a biomass concentration between 7 and $8 \mathrm{~g} \mathrm{~L}^{-1}$ in an USB reactor after $15 \mathrm{~d}$ of operation using real domestic wastewater. The USB reactor influent was supplemented with sodium nitrate and operated at a $\mathrm{NO}_{3}{ }^{-} \mathrm{-N}$ loading rate of $360 \pm 90$ $\mathrm{mg} \mathrm{L}^{-1} \mathrm{~d}^{-1}$ [11]. Du et al. [12] applied USB reactor coupled with anaerobic ammonia oxidation (anammox) process to achieve $89 \%$ total nitrogen removal in treating synthetic wastewater rich in $\mathrm{NO}_{3}{ }^{-}$at a high $\mathrm{NO}_{3}{ }^{-} \mathrm{N}$ loading rate of $720 \mathrm{mg} \mathrm{L}^{-1} \mathrm{~d}^{-1}$. Jin et al. [13] has also successfully operated an USB reactor with high biomass concentration $\left(130 \mathrm{~g} \mathrm{~L}^{-1}\right)$ and granular sludge (1.5-3.5 $\mathrm{mm}$ in diameter) to achieve high denitrification efficiency $(98 \%)$ at a nitrite nitrogen $\left(\mathrm{NO}_{2}{ }^{-}-\mathrm{N}\right)$ loading rate of $1200 \mathrm{mg} \mathrm{L}^{-1} \mathrm{~d}^{-1}$.

However, the use of USB reactor configuration for drinking water pre-treatment is still not well understood. A potential challenge of applying USB reactor for pretreating raw water polluted with $\mathrm{NO}_{3}{ }^{-}$is the treatment capacity. USB reactor was typically operated with a hydraulic retention time (HRT) between $8 \mathrm{~h}$ and $24 \mathrm{~h}$ for domestic wastewater treatment $[14,15]$. To meet the high treatment capacity of DWTPs, USB reactor must operate efficiently at lower HRTs, but the effect of HRT on the USB reactor performance for polluted raw water pre-treatment is still lacking in the literature. In contrast with wastewater, raw water contained very low concentration $\left(<5 \mathrm{mg} \mathrm{L}^{-1}\right)$ of organic carbon [2]. Biological denitrification requires sufficient organic carbon as electron donor, in theory $1.5 \mathrm{~g}$ of carbon is required to remove $1 \mathrm{~g}$ of $\mathrm{NO}_{3}{ }^{-}-\mathrm{N}$ by denitrification $[16,17]$. Thus, external carbon dosage was needed to enhance the denitrification performance. The common carbon sources commercially used include acetate, glucose, and methanol [18]. Methanol is the most widely used carbon source due to its high availability, biodegradability, and efficiency. However, methanol usage is hazardous as it is flammable, toxic, and highly reactive [19]. As an alternative solution, Peng et al. [20] suggested the use of acetate because it has low toxicity, high biodegradability and high $\mathrm{NO}_{3}{ }^{-}$utilization rate. An optimum dosage requirement expressed as carbon-to-nitrogen ratio $(\mathrm{C} / \mathrm{N})$ for raw water pre-treatment in the USB reactor is required to provide sufficient amount of carbon source for biological $\mathrm{NO}_{3}{ }^{-}$removal, at the same time over-dosage must be avoided to prevent carbon breakthrough in the effluent.

This study aimed to investigate the effect of $\mathrm{C} / \mathrm{N}$ on the $\mathrm{NO}_{3}{ }^{-}$removal performance of an USB reactor pretreating synthetic raw water contaminated with $\mathrm{NO}_{3}{ }^{-}$. A sequencing batch reactor (SBR) was first operated to study the optimal $\mathrm{C} / \mathrm{N}$ for biological denitrification pretreating the synthetic raw water. Subsequently, we applied the optimal $\mathrm{C} / \mathrm{N}$ in an USB reactor to monitor its denitrification performance and to examine opportunities to reduce the HRT of the reactor.

\section{Materials and methods SBR operation}

A SBR of 1-L working volume was set up (Fig. 1). The SBR was inoculated with activated sludge obtained from a domestic wastewater treatment plant in Kuala Lumpur, Malaysia operating in SBR configuration with a preanoxic selector. Synthetic raw water contaminated with $\mathrm{NO}_{3}{ }^{-}$was prepared according to the composition listed in Table 1. Sodium acetate and sodium nitrate were used as the dissolved organic carbon (DOC) and $\mathrm{NO}_{3}{ }^{-}$ sources, respectively. The synthetic raw water was autoclaved at $121{ }^{\circ} \mathrm{C}$ for $20 \mathrm{~min}$ immediately after preparation to prevent microbial consumption of DOC and $\mathrm{NO}_{3}{ }^{-}$for their growth.

Each SBR cycle consisted of five phases, including 15 min of filling phase, $300 \mathrm{~min}$ of reaction phase, $30 \mathrm{~min}$ of settling phase, $14 \mathrm{~min}$ of decanting phase and $1 \mathrm{~min}$

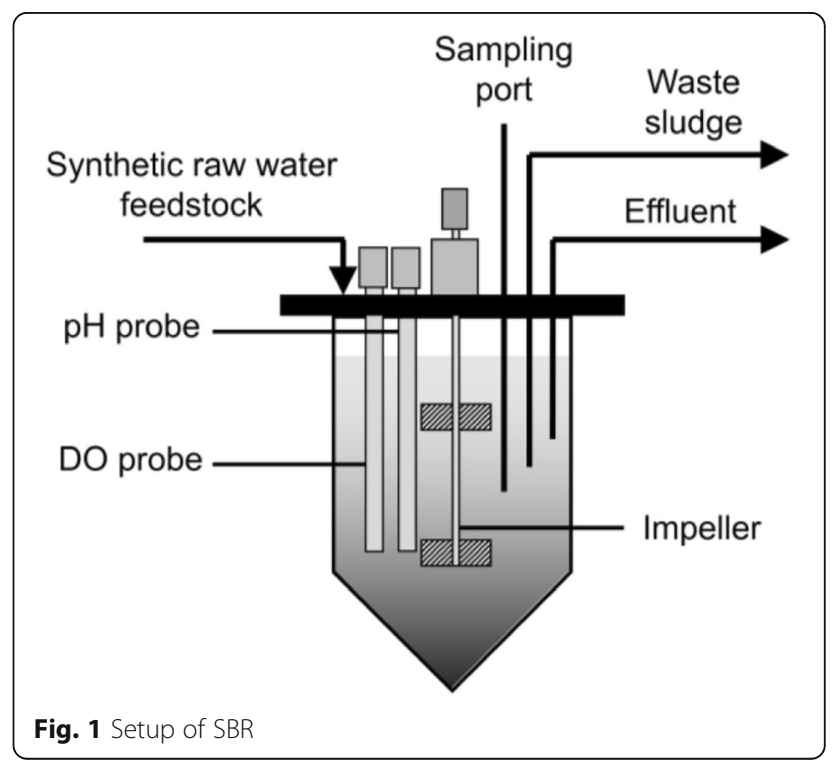


Table 1 Composition of synthetic raw water feedstock for SBR

\begin{tabular}{|c|c|c|c|}
\hline \multicolumn{2}{|l|}{ Macronutrient $\left(\mathrm{mg} \mathrm{L}^{-1}\right)$} & \multicolumn{2}{|l|}{ Micronutrient ( $\mathrm{mg} \mathrm{L}^{-1}$ ) } \\
\hline Sodium acetate & $228-456$ & Iron(II) sulfate heptahydrate & 1.49 \\
\hline Sodium nitrate & 202 & Boric acid & 0.17 \\
\hline Magnesium sulfate heptahydrate & 101 & Zinc sulfate heptahydrate & 0.13 \\
\hline Sodium sulfite & 100 & Manganese (II) chloride tetrahydrate & 0.11 \\
\hline Potassium hydrogen phosphate dibasic & 29 & Copper(II) sulfate pentahydrate & 0.04 \\
\hline Calcium chloride dihydrate & 18 & Sodium molybdate dihydrate & 0.01 \\
\hline
\end{tabular}

of idling phase [21, 22]. Anoxic condition in the SBR was achieved through the addition of $0.1 \mathrm{~g}$ of sodium sulfite per liter of synthetic raw water [23]. Sodium sulfite was added to ensure a controlled anoxic environment in the lab-scale SBR. The addition of sodium sulfite will not be required in full-scale DWTPs operation due to lower dissolved oxygen (DO) concentrations in real raw water. Mixed liquor within the reactor was agitated using a single impeller operating at $90 \mathrm{rpm}$ throughout the reaction phase. The sludge retention time (SRT) and HRT were set at $10 \mathrm{~d}$ and $10 \mathrm{~h}$, respectively. The SBR was operated at ambient temperature $\left(28 \pm 2{ }^{\circ} \mathrm{C}\right)$. The $\mathrm{DO}$ and $\mathrm{pH}$ of the reactor was monitored on-line using a M300 Process 2-channel $1 / 4$ DIN transmitter coupled with an InPro6850i DO probe and a 405-DPAS-SC-K851200 combination $\mathrm{pH} /$ temperature probe (Mettler-Toledo, US).

We operated the SBR for $22 \mathrm{~d}$ in three operating phases (SP1, SP2 and SP3 in Table 2). The $\mathrm{C} / \mathrm{N}$ of each operating phase was increased stepwise and operated for a week to monitor the denitrification performance at different $\mathrm{C} / \mathrm{N}$. Three sampling campaigns were carried out each week. In each sampling campaign, the mixed liquor samples were collected every $2 \mathrm{~h}$ for chemical analyses to monitor the evolution of DOC, nitrite $\left(\mathrm{NO}_{2}{ }^{-}\right)$and $\mathrm{NO}_{3}{ }^{-}$in the SBR.

\section{USB reactor operation}

We set up an USB reactor with a 2-L working volume (Fig. 2). The total height of the reactor was $100 \mathrm{~cm}$ with an internal diameter of $10 \mathrm{~cm}$, the spacing between each sampling port was $15 \mathrm{~cm}$. A purge gas recirculation line was installed to prevent floating sludge (Fig. 2). The nitrogen gas produced was recycled to the bottom of the USB reactor intermittently for $1 \mathrm{~min}$ every hour to purge

Table 2 Designed operating conditions of SBR

\begin{tabular}{llll}
\hline Operating phase & SP1 & SP2 & SP3 \\
\hline Days & $1-9$ & $10-15$ & $16-22$ \\
$\mathrm{C} / \mathrm{N}\left(\mathrm{g} \mathrm{C} \mathrm{g}^{-1} \mathrm{~N}\right)$ & 4 & 3 & 2 \\
$\mathrm{DOC}\left(\mathrm{mg} \mathrm{L}^{-1}\right)$ & 80 & 60 & 40 \\
$\mathrm{NO}_{3}{ }^{-} \mathrm{N}\left(\mathrm{mg} \mathrm{L}^{-1}\right)$ & 20 & 20 & 20 \\
\hline
\end{tabular}

the trapped nitrogen gas in the sludge flocs. We seeded the USB reactor with the same source of activated sludge for SBR as shown above. The synthetic raw water fed into the USB reactor was prepared by diluting the concentrated feedstock solution with tap water at a ratio of 1:5. Sodium acetate and potassium nitrate were used as the source of DOC and $\mathrm{NO}_{3}{ }^{-}$in the synthetic raw water, respectively. The macronutrient, micronutrient and phosphate feedstock solutions were mixed at a ratio of 1 : 0.0004:1 in the feed tank. The compositions of the USB reactor influent were listed in Table 3 . The synthetic raw water was fed into the USB reactor continuously using a peristaltic pump.

The HRT of the reactor was $3 \mathrm{~h}$. We operated the USB reactor at ambient temperature $\left(28 \pm 2{ }^{\circ} \mathrm{C}\right)$. We started up the reactor for $22 \mathrm{~d}$ to reach a stable denitrification performance with a $\mathrm{C} / \mathrm{N}$ of $3 \mathrm{~g} \mathrm{C} \mathrm{g}^{-1} \mathrm{~N}$. The reactor was subsequently operated in two consecutive operating phases (UP1 and UP2) to monitor the $\mathrm{NO}_{3}{ }^{-}$removal performance of the USB reactor (Table 4). Three sampling campaigns were performed per week to collect the influent and effluent samples at the bottom and top of the USB reactor, respectively. Additionally, detailed sampling campaign were conducted biweekly to show the evolution of carbon and nitrogen species along the vertical flow length of the reactor by collecting influent sample, effluent sample and mixed liquor samples from each of the sampling port (Fig. 2).

\section{Chemical analyses}

The $\mathrm{pH}$ of mixed liquor samples obtained from the USB reactor was measured using an $827 \mathrm{pH}$ Lab with Primatode (Metrohm, Switzerland). We filtered all the mixed liquor samples from the SBR and the USB reactor through a $0.2-\mu \mathrm{m}$ membrane filter for anion analysis $\left(\mathrm{NO}_{2}{ }^{-}\right.$and $\left.\mathrm{NO}_{3}{ }^{-}\right)$using an 861 Advanced Compact Ion Chromatograph (Metrohm, Switzerland). The DOC of the samples was measured using a TOC-V CSN total organic carbon analyzer (Shimadzu, Japan) after filtration through a $0.45-\mu \mathrm{m}$ membrane filter. The concentrations of mixed liquor suspended solids (MLSS) and mixed liquor volatile suspended solids (MLVSS) were determined according to the Standard Methods [24]. 


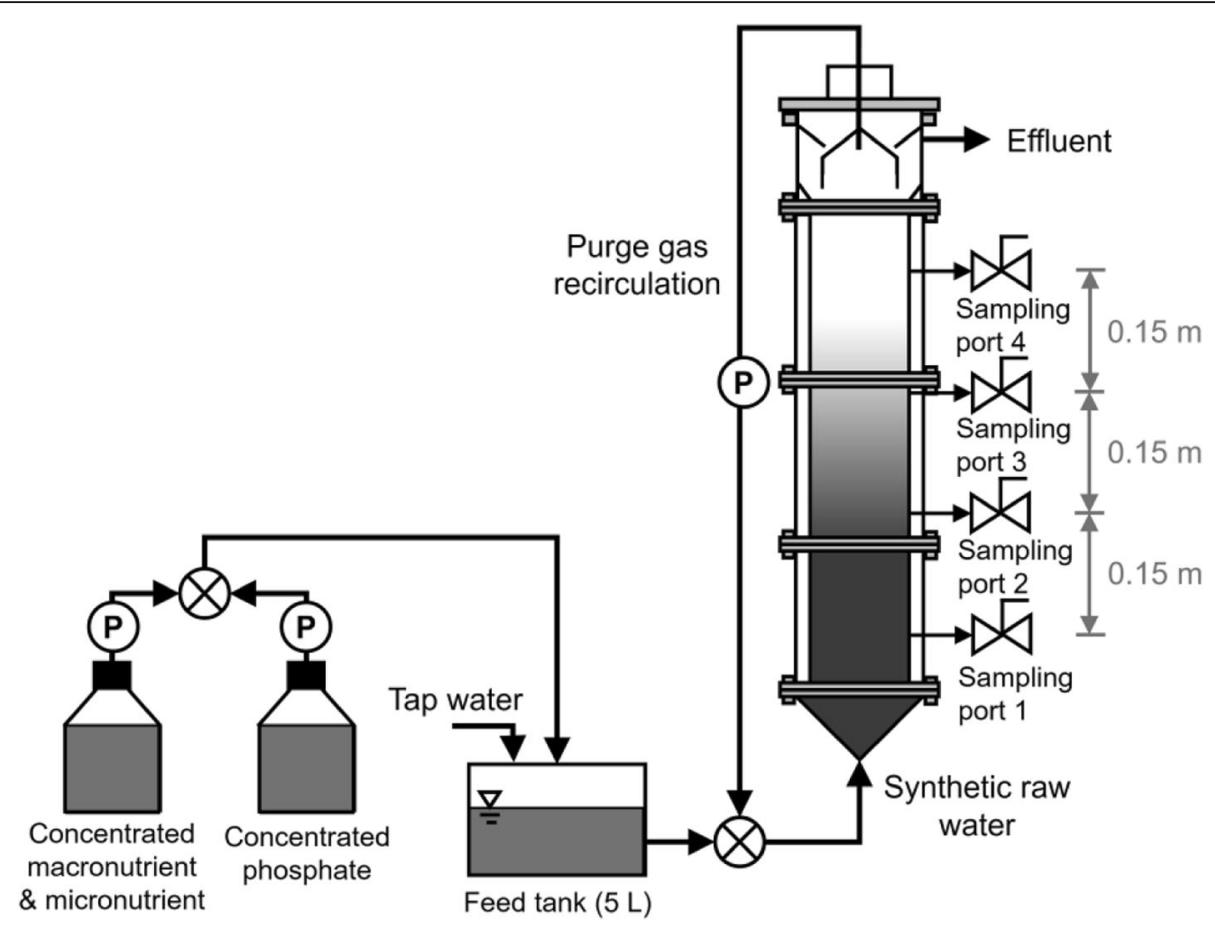

Fig. 2 Setup of USB reactor

Specific denitrification rate (SDNR) calculation The SDNR was calculated using Eq. (1).

$$
\mathrm{SDNR}=\frac{\Delta \mathrm{NO}_{\mathrm{x}}{ }^{-}-\mathrm{N}}{\mathrm{HRT} \times \mathrm{MLVSS}}
$$

where $\Delta \mathrm{NO}_{\mathrm{x}}{ }^{-}-\mathrm{N}\left(\mathrm{mg} \mathrm{L}^{-1}\right)$ was the sum of $\mathrm{NO}_{3}{ }^{-}-\mathrm{N}$ and 0.6 times $\mathrm{NO}_{2}{ }^{-}-\mathrm{N}$ removed in the reactor to account for the lower oxygen equivalent of $\mathrm{NO}_{2}^{-}$when compared with $\mathrm{NO}_{3}{ }^{-}$[25]. MLVSS and HRT were in the unit of $\mathrm{g}$ $\mathrm{L}^{-1}$ and $\mathrm{h}$, respectively.

\section{Results and discussion}

Effect of $\mathrm{C} / \mathrm{N}$ on denitrification performance in SBR

The SBR was operated for $22 \mathrm{~d}$ (Table 2). The $\mathrm{pH}$, DOC, $\mathrm{NO}_{3}{ }^{-}$and $\mathrm{NO}_{2}{ }^{-}$profiles under different $\mathrm{C} / \mathrm{N}$ in SP1, SP2 and SP3 are shown in Fig. 3. The $\mathrm{C} / \mathrm{N}$ was calculated from DOC, which was a normalized parameter for the measurement of organic carbon concentration from sodium acetate. The use of DOC allows fair comparison of reactor performance with other studies using different types of carbon source, such as methanol and ethanol, under similar C/N. In SP1 operated with a designed $\mathrm{C} / \mathrm{N}$ of $4 \mathrm{~g} \mathrm{C} \mathrm{g}^{-1} \mathrm{~N}$, the pH of the SBR (Fig. 3a)

Table 3 Composition of synthetic raw water for USB reactor

\begin{tabular}{|c|c|c|c|}
\hline \multicolumn{2}{|l|}{ Macronutrient $\left(\mathrm{mg} \mathrm{L}^{-1}\right)$} & \multicolumn{2}{|l|}{ Micronutrient $\left(\times 10^{-3} \mathrm{mg} \mathrm{L}^{-1}\right)$} \\
\hline Sodium acetate & $273-410$ & Ethylenediaminetetraacetic acid & 12 \\
\hline Potassium nitrate & 289 & Iron(III) chloride hexahydrate & 1.8 \\
\hline Magnesium chloride hexahydrate & 121 & Potassium iodide & 0.22 \\
\hline Magnesium sulfate heptahydrate & 68 & Boric acid & 0.18 \\
\hline Potassium hydrogen phosphate monobasic & 18 & Cobalt(II) chloride hexahydrate & 0.18 \\
\hline \multirow[t]{4}{*}{ Calcium chloride dihydrate } & 32 & Manganese (II) chloride tetrahydrate & 0.14 \\
\hline & & Zinc sulfate heptahydrate & 0.14 \\
\hline & & Sodium molybdate dihydrate & 0.07 \\
\hline & & Copper(II) sulfate pentahydrate & 0.04 \\
\hline
\end{tabular}


Table 4 Designed operating conditions of USB reactor

\begin{tabular}{lll}
\hline Operating phase & UP1 & UP2 \\
\hline Days & $1-6$ & $7-34$ \\
$\mathrm{C} / \mathrm{N}\left(\mathrm{g} \mathrm{C} \mathrm{g}^{-1} \mathrm{~N}\right)$ & 3 & 2 \\
$\mathrm{DOC}\left(\mathrm{mg} \mathrm{L}^{-1}\right)$ & 120 & 80 \\
$\mathrm{NO}_{3}{ }^{-}-\mathrm{N}\left(\mathrm{mg} \mathrm{L}^{-1}\right)$ & 40 & 40 \\
\hline
\end{tabular}

increased from 8.9-9.3 in the influent to 9.4 in the effluent due to the production of alkalinity during the denitrification process [26]. The initial DOC concentration in the SBR was $118.2 \pm 4.8 \mathrm{mg} \mathrm{L}^{-1}$, which was higher than the designed initial DOC concentration of $80 \mathrm{mg}$ $\mathrm{L}^{-1}$ (Table 2). The higher measured initial DOC concentration in the SBR was caused by DOC carryover from the previous SBR cycle. Based on the average unremoved DOC at the end of the cycle $\left(66.1 \pm 7.1 \mathrm{mg} \mathrm{L}^{-1}\right)$ in Fig. $3 \mathrm{~b}$ and a SBR volume exchange ratio of 0.6 , the DOC concentration in the feedstock before entering the SBR $\left(133 \mathrm{mg} \mathrm{L}^{-1}\right)$ will be diluted to $\left[\left(133.0 \mathrm{mg} \mathrm{L}^{-1} \times 0.6 \mathrm{~L}\right)+\right.$ $\left.\left(66.1 \mathrm{mg} \mathrm{L}{ }^{-1} \times 0.4 \mathrm{~L}\right)\right] / 1 \mathrm{~L}=106.2 \mathrm{mg} \mathrm{L}^{-1} \approx 110 \mathrm{mg} \mathrm{L}^{-1}$ in the SBR. Since the estimated DOC concentration at the start of cycle $\left(110 \mathrm{mg} \mathrm{L}^{-1}\right)$ agreed with our measured DOC concentration $\left(118.2 \pm 4.8 \mathrm{mg} \mathrm{L}^{-1}\right)$, we may reason that the higher initial DOC concentration in the SBR was caused by the carryover of unremoved DOC from the previous SBR cycle. The $\mathrm{NO}_{\mathrm{x}}{ }^{-}-\mathrm{N}$ removed, which was defined as the sum of $\mathrm{NO}_{3}{ }^{-}-\mathrm{N}$ and 0.6 times $\mathrm{NO}_{2}{ }^{-}-$ $\mathrm{N}$, during SP1 was $21.7 \pm 0.4 \mathrm{mg} \mathrm{L}^{-1}$, with negligible $\mathrm{NO}_{3}{ }^{-}-\mathrm{N}$ and $\mathrm{NO}_{2}{ }^{-}-\mathrm{N}$ at the end of SBR cycle (Fig. 3c and $\mathrm{d})$. A small amount of $\mathrm{NO}_{2}^{-}-\mathrm{N}\left(1.3 \pm 0.5 \mathrm{mg} \mathrm{L}^{-1}\right)$ was present at the start of the SBR reaction phase (Fig. 3d) because some $\mathrm{NO}_{3}{ }^{-}$could be reduced to $\mathrm{NO}_{2}{ }^{-}$by the heterotrophs during the anoxic filling phase. Based on the difference between the DOC at the beginning and at the end of the SBR reaction phase in SP1 (Fig. $3 \mathrm{~b}$ ), approximately $52.1 \pm 0.6 \mathrm{mg} \mathrm{L}^{-1}$ of DOC was consumed for both denitrification and cell synthesis. The theoretical concentration of $\mathrm{DOC}$ required to remove the $\mathrm{NO}_{\mathrm{x}}{ }^{-}-\mathrm{N}$ present at the start of the SBR reaction phase $\left(21.7 \pm 0.4 \mathrm{mg} \mathrm{L}^{-1}\right)$ was only $32.6 \mathrm{mg} \mathrm{L}^{-1}$ using a $\mathrm{C} / \mathrm{N}$ (expressed as a ratio between carbon and nitrogen) of $1.5 \mathrm{~g} \mathrm{C} \mathrm{g}^{-1} \mathrm{~N}$ [16]. The remaining DOC consumed $\left(19.5 \mathrm{mg} \mathrm{L}^{-1}\right)$ may be attributed to the cell synthesis. Thus, the high DOC concentration at the beginning of SBR cycle in SP1 $\left(118 \pm 5 \mathrm{mg} \mathrm{L}^{-1}\right.$, Fig. 3b) resulted in excess DOC supplied and significant carbon breakthrough in the effluent.

To reduce the carbon breakthrough in the effluent, we

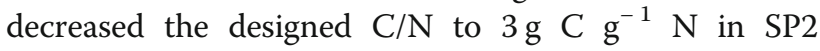
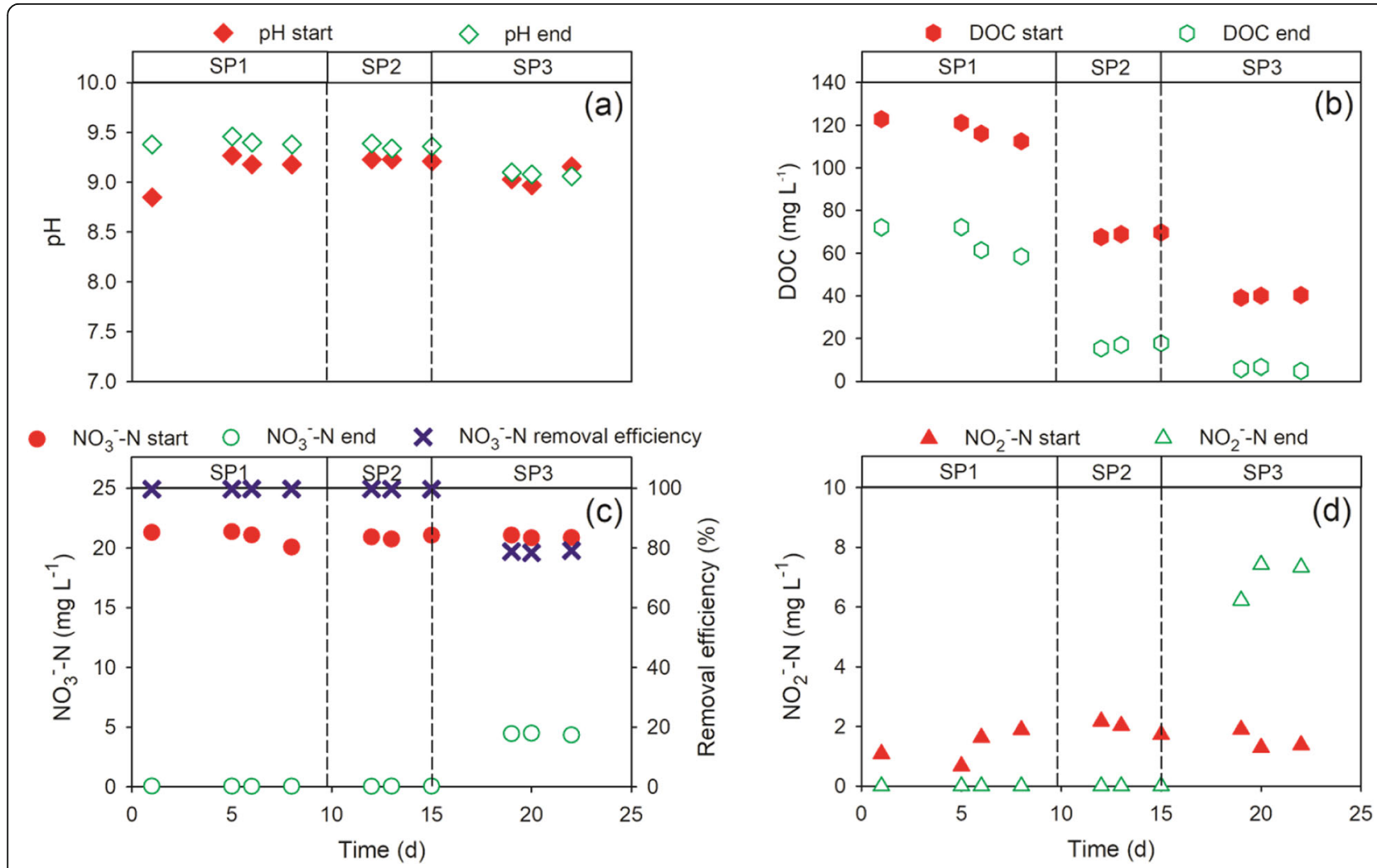

Fig. 3 The SBR profiles during SP1, SP2 and SP3. $\mathrm{pH}(\mathbf{a}), \mathrm{DOC}(\mathbf{b}), \mathrm{NO}_{3}{ }^{-} \mathrm{N}(\mathbf{c})$ and $\mathrm{NO}_{2}{ }^{-}-\mathrm{N}(\mathbf{d})$. The suffixes "start" and "end" refer to the beginning and end of the reaction phase, respectively 
(Table 2). The $\mathrm{pH}$ increased from 9.2 to 9.4 (Fig. 3a), indicating active denitrification in the SBR. The DOC concentration at the start of cycle was $68.8 \pm 1.1 \mathrm{mg} \mathrm{L}^{-1}$, which was slightly higher than the designed concentration of $60 \mathrm{mg} \mathrm{L}^{-1}$ due to the carryover of unremoved DOC from the previous cycle. The DOC at the end of cycle in SP2 $\left(16.7 \pm 1.3 \mathrm{mg} \mathrm{L}^{-1}\right.$; Fig. $\left.3 \mathrm{~b}\right)$ was 4 times lower than that in SP1 $\left(66.1 \pm 7.1 \mathrm{mg} \mathrm{L}^{-1}\right.$; Fig. 3b), thus indicating a significantly lower carbon breakthrough in the effluent during SP2 when compared with that during SP1. This implied that a designed $\mathrm{C} / \mathrm{N}$ of $3 \mathrm{~g} \mathrm{C} \mathrm{g}^{-1} \mathrm{~N}$ may be a suitable $\mathrm{C} / \mathrm{N}$ to be adopted for $\mathrm{NO}_{3}{ }^{-}$removal from polluted raw water, while ensuring minimal carbon breakthrough in the effluent. Similar to SP1, the effluent $\mathrm{NO}_{3}{ }^{-}-\mathrm{N}$ and $\mathrm{NO}_{2}{ }^{-}-\mathrm{N}$ were negligible and the $\mathrm{NO}_{\mathrm{x}}{ }^{-}-\mathrm{N}$ removed was $22.1 \pm 0.1 \mathrm{mg} \mathrm{L}^{-1}$ (Fig. $3 \mathrm{c}$ and d). From the DOC, $\mathrm{NO}_{3}{ }^{-}$and $\mathrm{NO}_{2}{ }^{-}$profiles in SP1 and SP2, the ratio of $\mathrm{DOC}$ to $\mathrm{NO}_{\mathrm{x}}{ }^{-} \mathrm{-N}$ consumed $\left(\mathrm{DOC} / \mathrm{NO}_{\mathrm{x}}{ }^{-} \mathrm{N}\right)$ to achieve complete denitrification was $2.4 \pm 0.1 \mathrm{~g} \mathrm{DOC} \mathrm{g}^{-1}$ $\mathrm{NO}_{\mathrm{x}}{ }^{-}-\mathrm{N}$. The calculated $\mathrm{DOC} / \mathrm{NO}_{\mathrm{x}}{ }^{-}-\mathrm{N}$ agreed with the $\mathrm{C} / \mathrm{N}$ range of 1.7 to $2.9 \mathrm{~g} \mathrm{C} \mathrm{g}^{-1} \mathrm{~N}$ typically applied for denitrification systems [17, 20, 27], which should be slightly higher than the theoretical $\mathrm{C} / \mathrm{N}$ of $1.5 \mathrm{~g} \mathrm{C} \mathrm{g}^{-1}$ $\mathrm{NO}_{\mathrm{x}}{ }^{-} \mathrm{-N}$ removed reported in the literature [16].

To validate that $\mathrm{DOC} / \mathrm{NO}_{\mathrm{x}}{ }^{-}-\mathrm{N}$ of $2.4 \mathrm{~g} \mathrm{C} \mathrm{g}^{-1} \mathrm{~N}$ was required for complete denitrification, we operated the SBR with a slightly lower designed $\mathrm{C} / \mathrm{N}$ of $2 \mathrm{~g} \mathrm{C} \mathrm{g}^{-1} \mathrm{~N}$ in SP3 (Table 2). The $\mathrm{pH}$ of the reaction mixture did not increase (Fig. 3a), which indicated a reduction in denitrification activity. The DOC concentration at the start of cycle in SP3 was $39.9 \pm 0.7 \mathrm{mg} \mathrm{L}^{-1}$, while its concentration reduced to $5.8 \pm 0.9 \mathrm{mg} \mathrm{L}^{-1}$ at the end of cycle (Fig. 3b). The $\mathrm{NO}_{3}{ }^{-}-\mathrm{N}$ and $\mathrm{NO}_{2}{ }^{-}-\mathrm{N}$ at the end of cycle were $4.4 \pm 0.1$ and $7.0 \pm 0.7 \mathrm{mg} \mathrm{L}^{-1}$, respectively (Fig. 3c and d), which was comparatively higher than the negligible $\mathrm{NO}_{3}{ }^{-}-\mathrm{N}$ and $\mathrm{NO}_{2}{ }^{-}-\mathrm{N}$ at the end of cycle during SP1 and SP2. The high $\mathrm{NO}_{2}{ }^{-}$concentration in the reactor exceeded the limit for drinking water $\left(3.0 \mathrm{mg} \mathrm{L}^{-1}\right)$ recommended by World Health Organization [3], which may cause lethal methemoglobinemia amongst infants. Thus, higher $\mathrm{C} / \mathrm{N}\left(>2.4 \mathrm{~g} \mathrm{C} \mathrm{g}^{-1} \mathrm{~N}\right)$ should be applied to prevent $\mathrm{NO}_{2}{ }^{-}$accumulation.

From the investigation of different $\mathrm{C} / \mathrm{N}(2,3$ and $4 \mathrm{~g} \mathrm{C}$ $\mathrm{g}^{-1} \mathrm{~N}$ ) in the SBR, we deduced that a designed $\mathrm{C} / \mathrm{N}$ of $3 \mathrm{~g} \mathrm{C} \mathrm{g}^{-1} \mathrm{~N}$ was the optimal ratio that should be applied for the subsequent USB reactor operation. By using a designed $\mathrm{C} / \mathrm{N}$ of $3 \mathrm{~g} \mathrm{C} \mathrm{g}^{-1} \mathrm{~N}$, the carbon breakthrough could be minimized while ensuring complete $\mathrm{NO}_{3}{ }^{-}$and $\mathrm{NO}_{2}{ }^{-}$removal from the synthetic raw water.

\section{Denitrification efficiency and SDNR in USB reactor}

After a stabilization period of $22 \mathrm{~d}$, the USB reactor was operated in UP1 (designed $\mathrm{C} / \mathrm{N}=3 \mathrm{~g} \mathrm{C}^{-1} \mathrm{~N}$ ) for 6 days (Table 4). Figure 4 shows the $\mathrm{pH}, \mathrm{DOC}, \mathrm{NO}_{3}{ }^{-}$and
$\mathrm{NO}_{2}{ }^{-}$profiles of the USB reactor. The $\mathrm{pH}$ of the reaction mixture in USB reactor increased from 7.3-8.6 in the influent to 8.7-9.5 in the effluent during UP1 (Fig. 4a). The larger magnitude of $\mathrm{pH}$ increases in the USB reactor when compared with that in the SBR was caused by the higher designed influent $\mathrm{NO}_{3}{ }^{-}-\mathrm{N}\left(40 \mathrm{mg} \mathrm{L}^{-1}\right)$ in the USB reactor in comparison to $20 \mathrm{mg} \mathrm{NO}_{3}^{-}{ }^{-} \mathrm{N} \mathrm{L}^{-1}$ in the SBR. The influent $\mathrm{pH}$ in the USB reactor (7.3-8.6) was also lower than that in the SBR after influent addition (9.1) because potassium hydrogen phosphate monobasic was used as the phosphate buffer during the USB reactor operation, while potassium hydrogen phosphate dibasic was used for the SBR operation. In UP1, the DOC concentration reduced from $98.9 \pm 23.5 \mathrm{mg} \mathrm{L}^{-1}$ in the influent to $62.1 \pm 12.9 \mathrm{mg} \mathrm{L}^{-1}$ (Fig. 4b). The influent DOC on day 6 was lower due to reactor operation error that caused denitrification along the transport tube from the feed tank to the USB reactor. Based on the ratio of the difference between the designed and measured influent DOC and $\mathrm{NO}_{\mathrm{x}}{ }^{-}-\mathrm{N}$ on day 6 , the $\mathrm{C} / \mathrm{N}$ for denitrification along the transport tube was $2.3 \mathrm{~g} \mathrm{DOC} \mathrm{g}^{-1}$ $\mathrm{NO}_{\mathrm{x}}{ }^{-}-\mathrm{N}$. The $\mathrm{C} / \mathrm{N}$ was similar to the ratio calculated from the SBR operation, which explained the partial denitrification of $\mathrm{NO}_{3}{ }^{-}$in the influent into $\mathrm{NO}_{2}{ }^{-}$at the entrance of the USB reactor. During UP1, Fig. 4c showed that only $15.1 \pm 2.4 \mathrm{mg} \mathrm{L}^{-1}$ of $\mathrm{NO}_{3}{ }^{-}-\mathrm{N}$ was present in the influent, while the influent $\mathrm{NO}_{2}{ }^{-}-\mathrm{N}$ was $17.8 \pm 6.3$ $\mathrm{mg} \mathrm{L}^{-1}$ (Fig. 4d). Thus, the sum of influent $\mathrm{NO}_{2}{ }^{-} \mathrm{N}$ and $\mathrm{NO}_{3}{ }^{-} \mathrm{-N}$ was $32.9 \pm 8.4 \mathrm{mg} \mathrm{L}^{-1}$, which was close to the designed influent $\mathrm{NO}_{3}{ }^{-}-\mathrm{N}\left(40 \mathrm{mg} \mathrm{L}^{-1}\right)$. Both $\mathrm{NO}_{3}{ }^{-}$and $\mathrm{NO}_{2}^{-}$was completely removed from the synthetic raw water with a low effluent $\mathrm{NO}_{3}{ }^{-}-\mathrm{N}\left(0.5 \pm 0.1 \mathrm{mg} \mathrm{L}^{-1}\right)$ and $\mathrm{NO}_{2}{ }^{-}-\mathrm{N}(\approx 0)$. Based on the concentrations of DOC $\left(36.9 \pm 17.2 \mathrm{mg} \mathrm{L}^{-1}\right)$ and $\mathrm{NO}_{\mathrm{x}}{ }^{-}-\mathrm{N}\left(25.3 \pm 6.0 \mathrm{mg} \mathrm{L}^{-1}\right)$ removed in UP1, the calculated $\mathrm{DOC} / \mathrm{NO}_{\mathrm{x}}{ }^{-}-\mathrm{N}$ was $1.4 \pm$ $0.4 \mathrm{~g} \mathrm{DOC} \mathrm{g}^{-1} \mathrm{NO}_{\mathrm{x}}{ }^{-} \mathrm{N}$. The ratio was lower than the calculated ratio in the SBR $\left(2.4 \pm 0.1 \mathrm{~g}^{\mathrm{DOC}} \mathrm{g}^{-1} \mathrm{NO}_{\mathrm{x}}{ }^{-}\right.$$\mathrm{N})$ and along the transport tube on day 6 during UP1

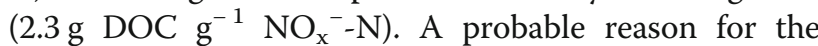
lower DOC/ $/ \mathrm{NO}_{\mathrm{x}}{ }^{-}-\mathrm{N}$ was the long SRT operation of USB reactor because the sludge in the reactor was not wasted regularly, when compared with a SRT of $10 \mathrm{~d}$ in the SBR. Nonetheless, the true SRT of the USB reactor should be evaluated in the future works considering small amount of the floating sludge that discharged together with the effluent. The longer SRT of USB reactor could promote sludge hydrolysis that supplemented the carbon source $[28,29]$, thus the DOC supplied to the reactor may not be fully utilized for denitrification. We may further reduce the $\mathrm{C} / \mathrm{N}$ of the USB reactor influent due to the lower required $\mathrm{DOC} / \mathrm{NO}_{\mathrm{x}}{ }^{-}-\mathrm{N}$. The reduction in the influent $\mathrm{C} / \mathrm{N}$ could lower the carbon breakthrough observed in UP1 $\left(62.1 \pm 12.9 \mathrm{mg} \mathrm{L}^{-1}\right)$. 


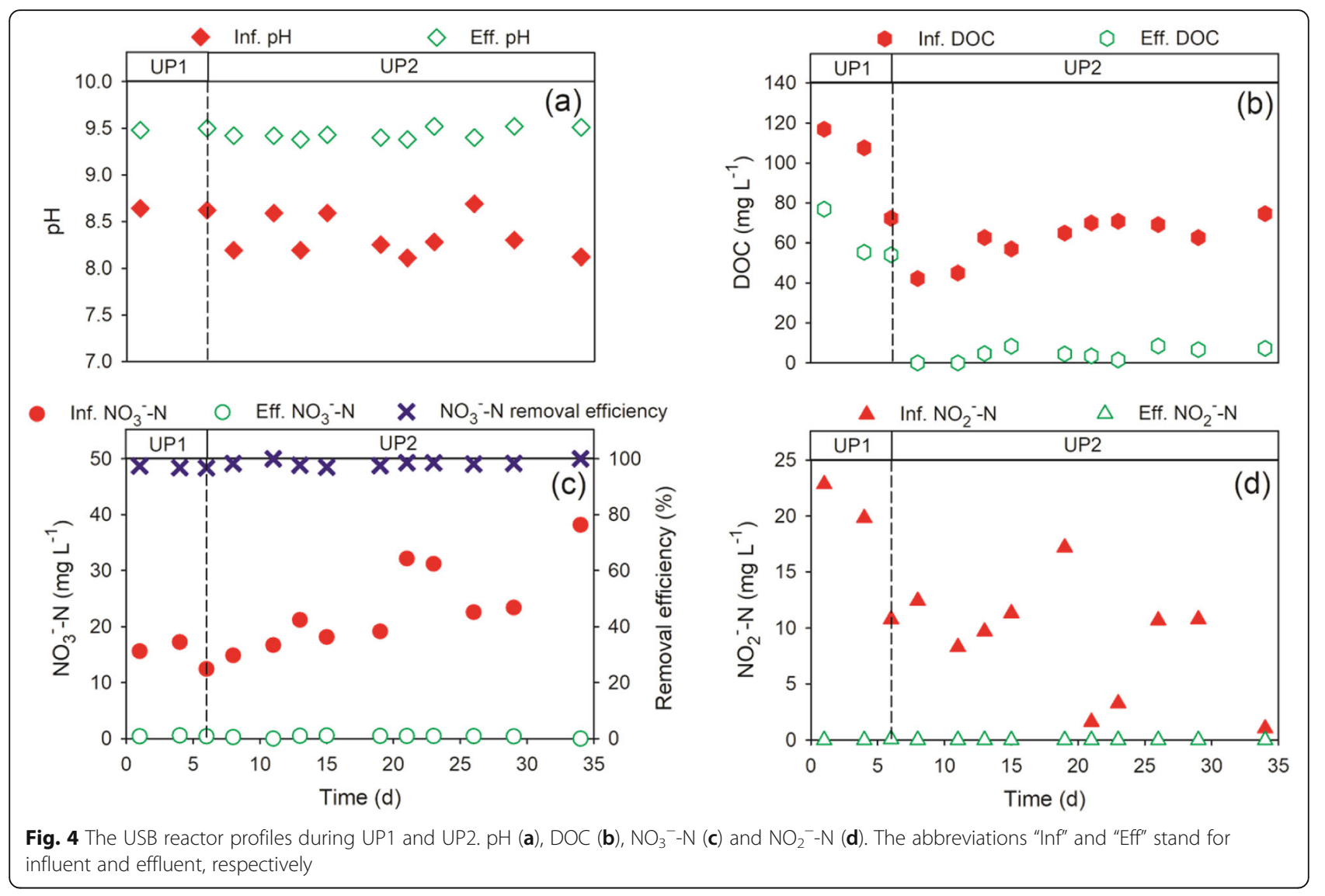

Subsequently, we operated the USB reactor for $28 \mathrm{~d}$ in UP2 (designed $\mathrm{C} / \mathrm{N}=2 \mathrm{~g} \mathrm{C} \mathrm{g}^{-1} \mathrm{~N}$; Table 4). In UP2, the $\mathrm{pH}$ of the USB reactor increased from 8.1-8.7 in the influent to 9.4-9.5 in the effluent (Fig. 4a). Figure 4b shows that the carbon breakthrough in UP2 significantly improved with an effluent DOC $\left(4.5 \pm 3.2 \mathrm{mg} \mathrm{L}^{-1}\right)$, or 12 times lower than that in UP1 $\left(62.1 \pm 12.9 \mathrm{mg} \mathrm{L}^{-1}\right)$, which may serve as a practical guideline for the DWTPs' operators to adopt a lower designed $\mathrm{C} / \mathrm{N}$ of $2.0 \mathrm{~g} \mathrm{C} \mathrm{g}^{-1} \mathrm{~N}$ when pre-treating raw water contaminated with $\mathrm{NO}_{3}{ }^{-}$ using an USB reactor. At the same time, the USB reactor achieved complete denitrification with effluent $\mathrm{NO}_{3}{ }^{-} \mathrm{N}$ and $\mathrm{NO}_{2}{ }^{-} \mathrm{N}$ of $0.2 \pm 0.1 \mathrm{mg} \mathrm{L}^{-1}$ and close to 0 , respectively (Fig. 4c and d). The corresponding $\mathrm{NO}_{3}{ }^{-}$and $\mathrm{NO}_{2}{ }^{-}$ removal efficiencies were $99 \pm 1 \%$ and near $100 \%$, respectively. The USB reactor operation in UP2 implied a designed $\mathrm{C} / \mathrm{N}$ of $2 \mathrm{~g} \mathrm{C} \mathrm{g}^{-1} \mathrm{~N}$ was sufficient for an USB reactor system pre-treating synthetic raw water with $\mathrm{NO}_{3}{ }^{-}-\mathrm{N}$ loading rate of $320 \mathrm{mg} \mathrm{L}^{-1} \mathrm{~d}^{-1}$ to achieve a high denitrification efficiency with a HRT of $3 \mathrm{~h}$. The HRT applied in this study was relatively shorter than other denitrification reactors with a similar or lower $\mathrm{NO}_{3}{ }^{-}-\mathrm{N}$ loading rate and $\mathrm{C} / \mathrm{N}$ (all expressed in $\mathrm{g} \mathrm{C}^{-1} \mathrm{~N}$ ) in Table 5 [5, 11, 16, 30, 31]. For instance, Her et al. [30] reported a $\mathrm{NO}_{3}{ }^{-}$removal efficiency of $97-99 \%$ in a batch denitrification system treating synthetic wastewater $\left(\mathrm{C} / \mathrm{N}=1.9 \mathrm{~g} \mathrm{C} \mathrm{g} \mathrm{g}^{-1} \mathrm{~N}, \mathrm{HRT}=12 \mathrm{~h}, \mathrm{NO}_{3}{ }^{-}{ }^{-} \mathrm{N}\right.$ loading rate $\left.=100 \mathrm{mg} \mathrm{L}^{-1} \mathrm{~d}^{-1}\right)$. Chen et al. [5] needed a HRT of $24 \mathrm{~h}$ for complete $\mathrm{NO}_{3}{ }^{-}$removal in a freshwater batch denitrification system operated with a $\mathrm{C} /$ $\mathrm{N}$ of $3.0-5.0 \mathrm{~g} \mathrm{C} \mathrm{g}^{-1} \mathrm{~N}$ and a $\mathrm{NO}_{3}{ }^{-}-\mathrm{N}$ loading rate of $5 \mathrm{mg} \mathrm{L}^{-1} \mathrm{~d}^{-1}$. Similarly, a batch biofilm reactor with a $\mathrm{C} / \mathrm{N}$ of $1.1 \mathrm{~g} \mathrm{C} \mathrm{g}^{-1} \mathrm{~N}$ and $\mathrm{a} \mathrm{NO}_{3}{ }^{-}-\mathrm{N}$ loading rate of $4 \mathrm{mg} \mathrm{L}^{-1} \mathrm{~d}^{-1}$ required a HRT of $24 \mathrm{~h}$ to remove $82 \%$ of the total nitrogen from the synthetic polluted water [31]. Dahab et al. [16] also reported an upflow packed bed reactor operated with a $\mathrm{C} / \mathrm{N}$ and a $\mathrm{NO}_{3}{ }^{-}-\mathrm{N}$ loading rate of $1.5 \mathrm{~g} \mathrm{C} \mathrm{g}^{-1} \mathrm{~N}$ and $267 \mathrm{mg}$ $\mathrm{L}^{-1} \mathrm{~d}^{-1}$, respectively, but needed a longer HRT of $9 \mathrm{~h}$ to achieve near complete $\mathrm{NO}_{3}{ }^{-}$removal from their synthetic raw water. In contrast, Watari et al. [11] reported that a HRT of $3 \mathrm{~h}$ in an USB reactor operated at a $\mathrm{C} / \mathrm{N}$ and a $\mathrm{NO}_{3}^{-}-\mathrm{N}$ loading rate of $1.4 \mathrm{~g} \mathrm{C} \mathrm{g}^{-1}$ $\mathrm{N}$ and $360 \pm 90 \mathrm{mg} \mathrm{L}^{-1} \mathrm{~d}^{-1}$, respectively, attained a poor $\mathrm{NO}_{3}{ }^{-}$removal efficiency (35\%). The poor denitrification performance was attributed to the decreasing wastewater temperature from 27 to $10^{\circ} \mathrm{C}$ during the winter months in Japan [11]. 
Table 5 Comparison of reactor configuration, operating conditions, influent compositions and denitrification efficiency between the USB reactor and other studies

\begin{tabular}{|c|c|c|c|c|c|c|c|}
\hline Reactor configuration & HRT (h) & Carbon source & $\begin{array}{l}\text { Influent } \mathrm{NO}_{3}{ }^{-} \mathrm{N} \\
\left(\mathrm{mg} \mathrm{L}^{-1}\right)\end{array}$ & $\begin{array}{l}\text { Influent } \mathrm{C} / \mathrm{N} \\
\left(\mathrm{g} C \mathrm{~g}^{-1} \mathrm{~N}\right)\end{array}$ & $\begin{array}{l}\mathrm{NO}_{3}{ }^{-}-\mathrm{N} \text { loading } \\
\text { rate }\left(\mathrm{mg} \mathrm{L}^{-1} \mathrm{~d}^{-1}\right)\end{array}$ & $\begin{array}{l}\mathrm{NO}_{3}{ }^{-}-\mathrm{N} \text { removal } \\
\text { efficiency (\%) }\end{array}$ & Reference \\
\hline USB & 3 & Sodium acetate & 40 & $2-3$ & 320 & $99 \pm 1$ & This study \\
\hline $\begin{array}{l}\text { Batch denitrification } \\
\text { experiment }\end{array}$ & 12 & Acetic acid & 50 & 1.9 & 100 & $97-99$ & [30] \\
\hline $\begin{array}{l}\text { Batch denitrification } \\
\text { experiment }\end{array}$ & 24 & Sodium acetate & 5 & $3-5$ & 5 & $>99$ & [5] \\
\hline $\begin{array}{l}\text { Batch biofilm } \\
\text { reactor }\end{array}$ & 24 & $\begin{array}{l}\text { Sodium acetate with } \\
\text { rice straw/rice husk }\end{array}$ & 4 & 1.1 & 4 & 82 & [31] \\
\hline $\begin{array}{l}\text { Upflow packed } \\
\text { bed column }\end{array}$ & 9 & Acetic acid & 100 & 1.5 & 267 & $>99$ & [16] \\
\hline USB & 3 & Raw sewage & $32.9 \pm 11.0$ & 1.4 & $360 \pm 90$ & 35 & [11] \\
\hline
\end{tabular}

To explore opportunities for HRT reduction to achieve the high treatment capacity required for raw water pretreatment, we examined the detailed $\mathrm{pH}, \mathrm{NO}_{\mathrm{x}}{ }^{-}$and DOC profiles of the USB reactor during UP2 (Fig. 5). The detailed profile indicated that the denitrification reaction was completed by the first sampling port (flow length $=0.15 \mathrm{~m}$ ). The $\mathrm{pH}$ of the reaction mixture increased from 8.2 to 9.4, after which the $\mathrm{pH}$ remained constant from the first sampling port to the effluent outlet (flow length $=0.75 \mathrm{~m}$ ). In line with the increasing $\mathrm{pH}$ trend, we observed concomitant removal in DOC and $\mathrm{NO}_{\mathrm{x}}{ }^{-}$in the USB reactor from the influent inlet to the first sampling port. The $\mathrm{DOC}$ and $\mathrm{NO}_{\mathrm{x}}{ }^{-} \mathrm{-N}$ at the first sampling port were $16.2 \pm 3.1$ and $0.4 \pm 0.1 \mathrm{mg} \mathrm{L}^{-1}$ (Fig.
5). The concentrations of $\mathrm{DOC}$ and $\mathrm{NO}_{\mathrm{x}}{ }^{-}$remained relatively constant from the first sampling port to the effluent outlet. The effluent DOC and $\mathrm{NO}_{\mathrm{x}}{ }^{-} \mathrm{-N}$ were $6.9 \pm$ 0.5 and $0.3 \pm 0.2 \mathrm{mg} \mathrm{L}^{-1}$, respectively (Fig. 5). Thus, the HRT may be reduced to $36 \mathrm{~min}$, which was one-fifth of the HRT of our USB reactor. By using Eq. (1) and a HRT of $36 \mathrm{~min}$, the SDNR of the USB reactor was $18.7 \pm 3.6 \mathrm{mg} \mathrm{Ng}^{-1}$ MLVSS $\mathrm{h}^{-1}$. The calculated SDNR for our USB reactor was within the range reported in the literature (10-24 $\mathrm{mg} \mathrm{N} \mathrm{g}^{-1}$ MLVSS h$\left.^{-1}\right)$ [12, 13, 32]. The high SDNR of USB reactor could lead to potential reduction in HRT, which could be a promising technology for DWTPs to pre-treat raw water contaminated with $\mathrm{NO}_{3}{ }^{-}$.

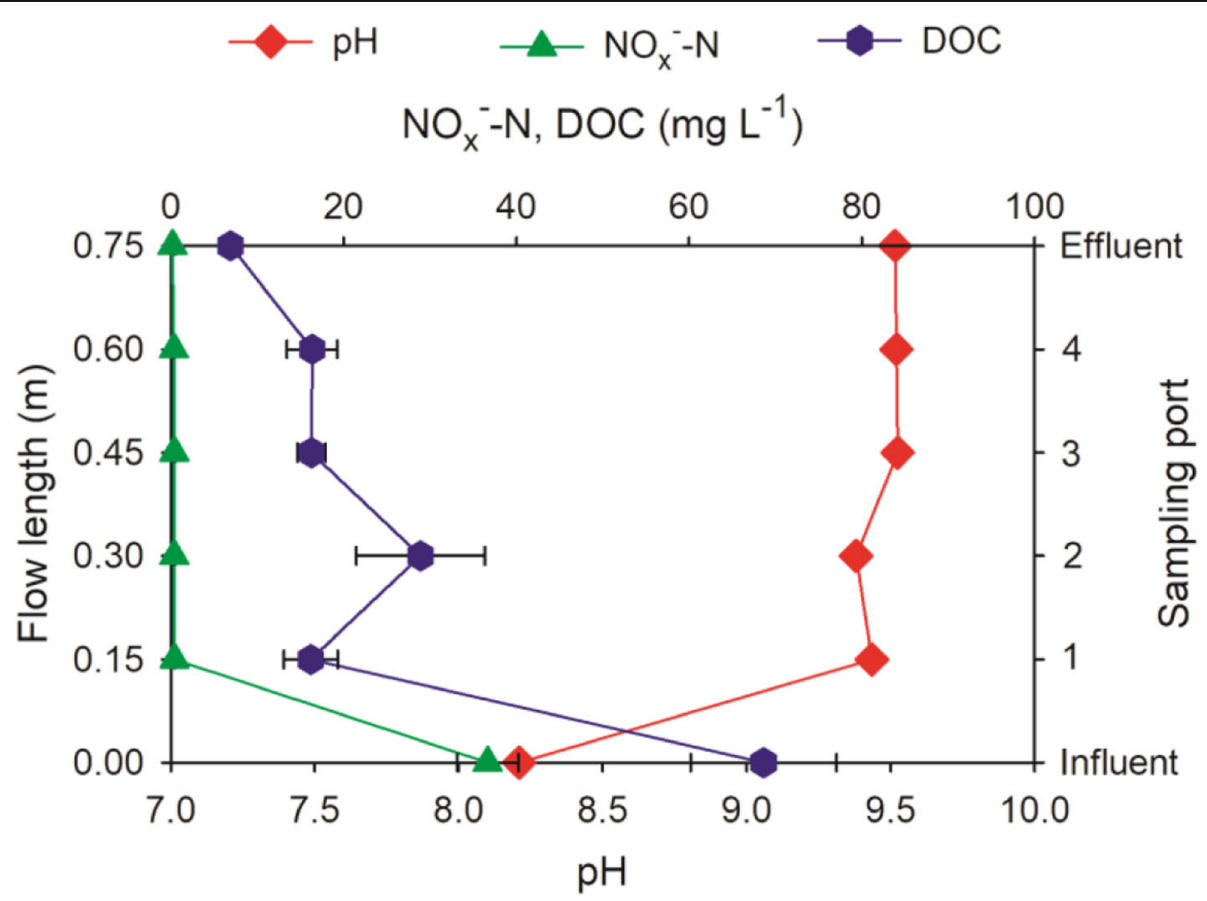

Fig. 5 The detailed $\mathrm{pH}, \mathrm{NO}_{x}{ }^{-}-\mathrm{N}$ and DOC profile of USB reactor during UP2 


\section{Implications on the design of DWTPs}

Most of the DWTPs in the developing countries are currently using conventional treatment processes consisting of physical and chemical process (precipitation, sedimentation, sand filtration and chlorination) [4], which necessitated a robust pre-treatment technology to remove $\mathrm{NO}_{3}{ }^{-}$from the raw water during pollution. Biological denitrification was the most effective and economical method for $\mathrm{NO}_{3}{ }^{-}$removal from polluted raw water [33]. Besides the USB reactor proposed in this study, biofilm reactor is another common biological denitrification technology reported for polluted raw water pre-treatment $[31,34]$. A major advantage of the USB reactor proposed in this study was the relatively shorter HRT $(3 \mathrm{~h})$ required for near complete removal of $\mathrm{NO}_{\mathrm{x}}{ }^{-}$ from the synthetic raw water contaminated with $\mathrm{NO}_{3}{ }^{-}$ when compared with other biofilm reactors $(24 \mathrm{~h})$ [31, 34]. Since near complete $\mathrm{NO}_{3}{ }^{-}$and $\mathrm{NO}_{2}{ }^{-}$removal was surprisingly achieved at one-fifth of the total reactor flow length, we recommend a tracer study to gain a better understanding on the hydrodynamics inside the USB reactor and the HRT may be further reduced to $36 \mathrm{~min}$ or shorter. Thus, the USB reactor may be a promising pre-treatment process necessary for high-rate $\mathrm{NO}_{3}{ }^{-}$removal in DWTPs operating with a high treatment capacity.

We also found that the DOC/ $\mathrm{NO}_{\mathrm{x}}{ }^{-} \mathrm{N}$ of the USB re-

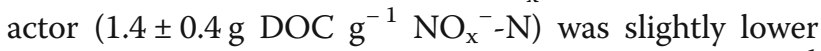
than the theoretical $\mathrm{C} / \mathrm{N}$ for denitrification $\left(1.5 \mathrm{~g} \mathrm{C} \mathrm{g}^{-1}\right.$ N) $[16,17]$. The long SRT of USB reactor could have promoted sludge hydrolysis to supplement carbon source for denitrification $[28,29]$. Thus, adopting USB reactor for polluted raw water pre-treatment may require smaller amount of external carbon sources than the amount calculated based on theoretical $\mathrm{C} / \mathrm{N}$ to save cost.

In addition, $\mathrm{NO}_{3}{ }^{-}$pollution in raw water sources occurred seasonally $[1,2]$. Therefore, further investigations are required to study the resilience of USB reactor to recover its denitrification performance after a prolonged period of low $\mathrm{NO}_{3}{ }^{-} \mathrm{N}\left(<1 \mathrm{mg} \mathrm{L}^{-1}\right)$ in the raw water source [2]. The prolonged low $\mathrm{NO}_{3}{ }^{-}$in the raw water source may cause a lower biomass concentration than those reported for USB reactors treating domestic wastewater (7-130 mg MLVSS L $\mathrm{L}^{-1}$ ) [11-13]. The impact of potentially lower biomass concentration in the USB reactor for pre-treating raw water should be investigated during the prolonged exposure to low influent $\mathrm{NO}_{3}{ }^{-}$.

\section{Conclusions}

An USB reactor for pre-treating synthetic raw water contaminated with $\mathrm{NO}_{3}{ }^{-}$was successfully started up in this study. A SBR was first operated to determine a suitable $\mathrm{C} / \mathrm{N}$ for biological denitrification pre-treating synthetic raw water, a designed $\mathrm{C} / \mathrm{N}$ of $3 \mathrm{~g} \mathrm{C}^{-1} \mathrm{~N}$ was the optimum ratio to achieve complete denitrification. An USB reactor was then operated at designed $\mathrm{C} / \mathrm{N}$ of 3 and $2 \mathrm{~g} \mathrm{C} \mathrm{g}^{-1} \mathrm{~N}$, a designed $\mathrm{C} / \mathrm{N}$ ratio of $2 \mathrm{~g} \mathrm{C} \mathrm{g}^{-1} \mathrm{~N}$ was more suitable for USB reactor to prevent carbon breakthrough. The USB reactor achieved a high SDNR $\left(18.7 \pm 3.6 \mathrm{mg} \mathrm{N} \mathrm{g}^{-1} \mathrm{VSS} \mathrm{h}^{-1}\right)$, which suggested opportunities to reduce the HRT $(\leq 36 \mathrm{~min})$. Future studies should investigate the USB reactor performance at shorter HRTs to achieve a high treatment capacity required for raw water pre-treatment. We also recommend to address the resilience of USB reactor system to cope with prolonged low $\mathrm{NO}_{3}{ }^{-}$in the raw water in future research. Overall, the USB reactor was a promising pretreatment technology necessary for DWTPs in the developing countries to polish up polluted raw water with $\mathrm{NO}_{3}{ }^{-}$prior to entering the drinking water treatment process train, thereby ensuring uninterrupted supply of safe drinking water.

\section{Acknowledgements}

The authors wish to thank Indah Water Konsortium Sdn. Bhd. for providing the activated sludge in this study. We would also like to thank Mr. Jutaro

Tsuboi for assisting in collecting mixed liquor samples from the USB reactor.

\section{Authors' contributions}

SWH prepared and revised the manuscript draft, and also involved in methodology development, formal analysis and presentation of reactor performance data. CXT, JYY and CYK contributed equally to the conceptualization of reactor study, methodology development, experiment investigation and formal analysis of reactor performance data. CKT and WY were involved in reviewing the data presentation in the manuscript and provided supervisions on the experiment planning. KS provided supervision on reactor operation, project administration and funding acquisition for the study. ASMC was the project principal investigator who contributed to experiment supervision, project administration and funding acquisition. All authors reviewed and approved the final manuscript.

\section{Funding}

This work was financially supported by the Ministry of Higher Education Malaysia Fundamental Research Grant Scheme (reference number FRGS/1/ 2017/TK02/UM/02/10; grant ID FP047-2017A).

Availability of data and materials

The data used to support the findings of this study are available from the corresponding author upon request.

\section{Declarations}

\section{Competing interests}

The authors declare they have no competing interests.

\section{Author details}

'Department of Chemical Engineering, Faculty of Engineering, Universiti Malaya, 50603 Kuala Lumpur, Malaysia. ${ }^{2}$ Department of Environmental Engineering, Faculty of Engineering, Kasetsart University, Bangkok 10900, Thailand. ${ }^{3}$ Center for Regional Environmental Research, National Institute for Environmental Studies, Tsukuba 305-8506, Japan. 
Received: 9 October 2020 Accepted: 3 March 2021

Published online: 25 March 2021

\section{References}

1. Atiqah A, Syafawanie A, Syafiqah A, Izhar I, Zarif M, Abdelazim A, et al. Hydrogeological and environmental study of Sungai Serai, Hulu Langat. Pak J Geol. 2017;1:8-11.

2. KeTSA. Study on the river water quality trends and indexes in Peninsular Malaysia. Putrajaya: Ministry of Natural Resources and Environment Malaysia; 2009.

3. WHO. Guidelines for drinking-water quality. 4th ed. Geneva: World Health Organization; 2017

4. Zinn C, Bailey R, Barkley N, Walsh MR, Hynes A, Coleman T, et al. How are water treatment technologies used in developing countries and which are the most effective? An implication to improve global health. J Public Health Emerg. 2018;2:25.

5. Chen $\mathrm{R}$, Deng $M$, He XG, Hou J. Enhancing nitrate removal from freshwater pond by regulating carbon/nitrogen ratio. Front Microbiol. 2017:8:1712.

6. Shrimali M, Singh KP. New methods of nitrate removal from water. Environ Pollut. 2001:112:351-9.

7. Du R, Cao SB, Niu M, Li BK, Wang SY, Peng YZ. Performance of partialdenitrification process providing nitrite for anammox in sequencing batch reactor (SBR) and upflow sludge blanket (USB) reactor. Int Biodeter Biodegr. 2017;122:38-46

8. How SW, Nittami T, Ngoh GC, Curtis TP, Chua ASM. An efficient oxic-anoxic process for treating low COD/N tropical wastewater: startup, optimization and nitrifying community structure. Chemosphere. 2020;259:127444.

9. Narayanan CM, Narayan V. Biological wastewater treatment and bioreactor design: a review. Sustain Environ Res. 2019;29:33.

10. Pagacova P, Galbova K, Drtil M, Jonatova I. Denitrification in USB reactor with granulated biomass. Bioresour Technol. 2010;101:150-6.

11. Watari T, Kotcharoen W, Omine T, Hatamoto M, Araki N, Oshiki M, et al. Formation of denitrifying granules in an upflow sludge blanket reactor with municipal sewage and sodium nitrate feeding. Environ Technol Inno. 2020; 19:100861

12. Du R, Cao SB, Li BK, Zhang HY, Wang SY, Peng YZ. Synergy of partialdenitrification and anammox in continuously fed upflow sludge blanket reactor for simultaneous nitrate and ammonia removal at room temperature. Bioresour Technol. 2019;274:386-94.

13. Jin XB, Wang F, Liu GH, Liu YD. Characteristics of denitrifying granular sludge grown on nitrite medium in an upflow sludge blanket (USB) reactor. Water Sci Technol. 2012:65:1420-7.

14. Onodera T, Sase S, Choeisai P, Yoochatchaval W, Sumino H, Yamaguchi T, et al. High-rate treatment of molasses wastewater by combination of an acidification reactor and a USSB reactor. J Environ Sci Heal A. 2011;46:172131.

15. Tanaka H, Takahashi M, Yoneyama Y, Syutsubo K, Kato K, Nagano A, et al. Energy saving system with high effluent quality for municipal sewage treatment by UASB-DHS. Water Sci Technol. 2012;66:1186-94.

16. Dahab MF, Lee YW. Nitrate removal from water supplies using biological denitrification. J Water Pollut Con F. 1988;60:1670-4.

17. Phanwilai S, Noophan P, Li CW, Choo KH. Effect of COD:N ratio on biological nitrogen removal using full-scale step-feed in municipal wastewater treatment plants. Sustain Environ Res. 2020;30:24.

18. Lettinga G, van Velsen AFM, Hobma SW, de Zeeuw W, Klapwijk A. Use of the upflow sludge blanket (USB) reactor concept for biological wastewater treatment, especially for anaerobic treatment. Biotechnol Bioeng. 1980;22: 699-734.

19. Cherchi C, Onnis-Hayden A, El-Shawabkeh I, Gu AZ. Implication of using different carbon sources for denitrification in wastewater treatments. Water Environ Res. 2009:81:788-99.

20. Peng $Y Z, M a Y$, Wang SY. Denitrification potential enhancement by addition of external carbon sources in a pre-denitrification process. J Environ SciChina. 2007:19:284-9.

21. Ong YH, Chua ASM, Lee BP, Ngoh GC, Hashim MA. An observation on sludge granulation in an enhanced biological phosphorus removal process. Water Environ Res. 2012;84:3-8

22. How SW, Lim SY, Lim PB, Aris AM, Ngoh GC, Curtis TP, et al. Low-dissolvedoxygen nitrification in tropical sewage: an investigation on potential, performance and functional microbial community. Water Sci Technol. 2018; 77:2274-83.
23. Sinha V, Li K. Alternative methods for dissolved oxygen removal from water: a comparative study. Desalination. 2000;127:155-64.

24. APHA. Standard methods for the examination of water and wastewater. 20th ed. Washington, DC: American Public Health Association; 1998.

25. Tchobanoglous G, Stensel HD, Tsuchihashi R, Burton F, Abu-Orf M, Bowden $G$, et al. 5th ed. Wastewater engineering: treatment and resource recovery. New York: McGraw-Hill Education; 2014.

26. Henze M, van Loosdrecht MCM, Ekama GA, Brdjanovic D. 1st ed. Biological wastewater treatment: principles, modeling and design. London: IWA Publishing; 2008.

27. Sobieszuk P, Szewczyk KW. Estimation of $(C / N)$ ratio for microbial denitrification. Environ Technol. 2006;27:103-8

28. Miron $Y$, Zeeman $G$, van Lier JB, Lettinga $G$. The role of sludge retention time in the hydrolysis and acidification of lipids, carbohydrates and proteins during digestion of primary sludge in CSTR systems. Water Res. 2000;34: 1705-13.

29. Takahashi M, Ohya A, Kawakami S, Yoneyama Y, Onodera T, Syutsubo K, et al. Evaluation of treatment characteristics and sludge properties in a UASB reactor treating municipal sewage at ambient temperature. Int J Environ Res. 2011:5:821-6.

30. Her JJ, Huang JS. Influences of carbon source and C/N ratio on nitrate/ nitrite denitrification and carbon breakthrough. Bioresour Technol. 1995;54: 45-51.

31. Pi SY, Sun JY, Feng $L J$, Zhou JH. Performance and microbial diversity of denitrifying biofilms on polyurethane foam coupled with various solid carbon sources for nitrate-rich water purification. Int Microbiol. 2020;23:40513

32. Li W, Zheng P, Guo J, Ji JY, Zhang M, Zhang ZH, et al. Characteristics of selfalkalization in high-rate denitrifying automatic circulation (DAC) reactor fed with methanol and sodium acetate. Bioresour Technol. 2014;154:44-50.

33. Rezvani F, Sarrafzadeh MH, Ebrahimi S, Oh HM. Nitrate removal from drinking water with a focus on biological methods: a review. Environ Sci Pollut R. 2019:26:1124-41.

34. Yang GF, Feng $L$, Guo CR, Xia T, Xu XY, Zhu L. Performance improvement of raw water pretreatment process with pre-inoculation biofilm: feasibility and limiting factors. Biodegradation. 2017;28:111-23.

\section{Publisher's Note}

Springer Nature remains neutral with regard to jurisdictional claims in published maps and institutional affiliations.
Ready to submit your research? Choose BMC and benefit from:

- fast, convenient online submission

- thorough peer review by experienced researchers in your field

- rapid publication on acceptance

- support for research data, including large and complex data types

- gold Open Access which fosters wider collaboration and increased citations

- maximum visibility for your research: over $100 \mathrm{M}$ website views per year

At $\mathrm{BMC}$, research is always in progress.

Learn more biomedcentral.com/submissions 